\title{
Effects of nitric oxide-induced aldolase nitration on the glycolytic metabolites of mast cell
}

\author{
Y Sekar ${ }^{1 *}$, T Chul Moon $^{1}$, CM Slupsky ${ }^{2}$, AD Befus ${ }^{1,2}$ \\ From Canadian Society of Allergy and Clinical Immunology Annual Scientific Meeting 2009 \\ Halifax, Canada. 22-25 October 2009
}

Mast cells (MC) are primary effector cells of IgEmediated allergic inflammation. Nitric oxide $(\mathrm{NO})$ is a short-lived free radical that regulates MC activities including inhibition of MC degranulation. To elucidate the molecular mechanisms underlying the effects of $\mathrm{NO}$ in $\mathrm{MC}$, we investigated protein tyrosine nitration in human mast cell lines treated with the NO donor SNitrosoglutathione (SNOG). Using 2D gel western blot analysis with an anti-nitrotyrosine antibody together with mass spectroscopy, we identified aldolase A, an enzyme of the glycolytic pathway as a target for tyrosine nitration in MC. Human MC lines HMC-1 and LAD-2 were treated with SNOG and the total aldolase activity and the intracellular fructose 1,6 bisphosphate (FBP), the substrate for aldolase were measured using a standard aldolase assay. Nuclear Magnetic Resonance (NMR) was employed to define the metabolic changes associated with NO treatment. MC degranulation was measured using $\beta$-hexosaminidase assay. Aldolase A nitration was associated with reduction in the Michaelis constant $\left(K_{m}\right)$ and maximum velocity $\left(V_{\max }\right)$ of aldolase in HMC-1 and LAD-2. NMR analysis showed that despite these changes in activity of a critical enzyme in glycolysis, there was no significant change in total cellular ATP content, although the AMP/ATP ratio was altered. Elevated levels of lactate and pyruvate suggested that NO treatment enhanced glycolysis in MC. Moreover, reduction in MC aldolase activity was associated with increased intracellular levels of its substrate, fructose 1,6 bisphosphate (FBP). Interestingly, FBP inhibited IgE-mediated MC degranulation in LAD-2 cells. Inhibition of MC degranulation by FBP has the potential to regulate $\mathrm{MC}$ function through multiple signaling pathways including phospholipase C (PLC). We are currently dissecting the precise signaling pathways underlying the

${ }^{1}$ Pulmonary Research Group, Department of Medicine, Canada effects of FBP. Analyses of the possible links between aldolase nitration, altered FBP levels and the regulation of $\mathrm{MC}$ function will evaluate the potential immunoregulatory role of FBP in allergic and immune diseases.

Supported by: Canadian Institutes of Health Research, The Lung Association, Alberta \& NWT and $75^{\text {th }}$ Anniversary award, Department of Medicine, University of Alberta.

\section{Author details}

${ }^{1}$ Pulmonary Research Group, Department of Medicine, Canada . ${ }^{2}$ Magnetic Resonance Diagnostic Centre, University of Alberta, Edmonton, Canada.

Published: 12 May 2010

doi:10.1186/1710-1492-6-S1-P21

Cite this article as: Sekar et al:: Effects of nitric oxide-induced aldolase nitration on the glycolytic metabolites of mast cell. Allergy, Asthma \& Clinical Immunology 2010 6(Suppl 1):P21.

\section{Submit your next manuscript to BioMed Central and take full advantage of: \\ - Convenient online submission \\ - Thorough peer review \\ - No space constraints or color figure charges \\ - Immediate publication on acceptance \\ - Inclusion in PubMed, CAS, Scopus and Google Scholar \\ - Research which is freely available for redistribution \\ Submit your manuscript at www.biomedcentral.com/submit}

